\title{
Taxonomic Relationships within the Pan-Oriental Narrow-mouth Toad Microhyla ornata as Revealed by mtDNA Analysis (Amphibia, Anura, Microhylidae)
}

\author{
Masafumi Matsui ${ }^{1 *}$, Hiroharu Ito ${ }^{1}$, Tomohiko Shimada ${ }^{1}$, Hidetoshi Ota ${ }^{2}$, Srinivas K. Saidapur ${ }^{3}$, \\ Wichase Khonsue $^{4}$, Tomoko Tanaka-Ueno ${ }^{1,5}$ and Guan-Fu Wu ${ }^{6}$ \\ ${ }^{1}$ Graduate School of Human and Environmenal Studies, Kyoto University, Sakyo, Kyoto 606-8501, Japan \\ ${ }^{2}$ Tropical Biosphere Research Center, University of the Ryukyus, Nishihara, Okinawa 903-0213, Japan \\ ${ }^{3}$ Department of Zoology, Karnatak University, Dharwad-580 003, India \\ ${ }^{4}$ Department of Biology, Faculty of Science, Chulalongkorn University, Bangkok 10330, Thailand \\ ${ }^{5}$ Department of Cellular and Molecular Biology, Primate Research Institute, \\ Kyoto University, Kanrin, Inuyama, Aichi 484-8506, Japan \\ ${ }^{6}$ Chengdu Institute of Biology, Academia Sinica, Chengdu, \\ Sichuan, People's Republic of China
}

\begin{abstract}
A molecular phylogenetic survey was conducted using mtDNA sequences of $12 \mathrm{~S}$ and $16 \mathrm{~S}$ rRNA, and cyt-b genes to examine taxonomic relationships among populations of the Pan-Oriental microhylid, Microhyla ornata, from India, Bangladesh, Thailand, Laos, China, Taiwan, and the Ryukyu Archipelago of Japan. Two discrete clades are recognized within this species, one consisting of populations from India and Bangladesh, and the other encompassing the remaining populations. In the latter clade, populations from the Ryukyu Archipelago are clearly split from the rest (populations from Taiwan and the continent) with considerable degrees of genetic differentiations. Each of the three lineages is judged to represent a good species, and the name Microhyla ornata is restricted to the South Asian populations. For the populations from Taiwan and a wide region from China to Southeast Asia, the name Microhyla fissipes should be applied, whereas the Ryukyu populations are most appropriately referred to as Microhyla okinavensis, although further substantial genetic differentiations are recognized among some island group populations within this last species.
\end{abstract}

Key words: Microhyla ornata, Microhyla fissipes, Microhyla okinavensis, mtDNA sequence, taxonomy

\section{INTRODUCTION}

Microhyla ornata (Duméril and Bibron, 1841) is a smallsized, narrow-mouth toad, and is an inhabitant of lowlands and hills where it takes termites and ants among litters (Fei, 1999; Maeda and Matsui, 1999; Hirai and Matsui, 2000; Schleich and Kästle, 2002). The species was originally described from India and is now considered to have a very wide range of distribution from the Ryukyu Archipelago of Japan through Taiwan, southern China, Southeast Asia including northern Malay Peninsula, to Nepal, India, Sri Lanka and northeastern Pakistan (Fig. 1: Frost, 1985; Duellman, 1993; Inger, 1999; Zhao, 1999; Khan, 2000).

Besides M. ornata, there were several other Oriental

* Corresponding author. Phone: +81-75-753-6846;

FAX : +81-75-753-6846;

E-mail: fumi@zoo.zool.kyoto-u.ac.jp anurans of different lineages that were also considered as wide-ranging single species. In the last two decades, however, some of them have proved to include several cryptic species: Polypedates megacephalus Hallowell, 1861 was resurrected from $P$. leucomystax (Gravenhorst, 1829) (Matsui et al., 1986); Kalophrynus interlineatus (Blyth, 1855) was elevated from a subspecific status of $K$. pleurostigma Tschudi, 1838 (Matsui et al., 1996); and Fejervarya limnocharis (Gravenhorst, 1829) was shown to include some morphologically similar but reproductively isolated entities (Toda et al., 1998; Veith et al., 2001). These findings were achieved by employing the methods other than the conventional morphological one. In particular, recent arguments on the amphibian taxonomy, like those on many other groups of organisms, tend to have their bases on the results of molecular analyses (e.g., Matsui, 1994; Toda et al., 1998; Veith et al., 2001). 


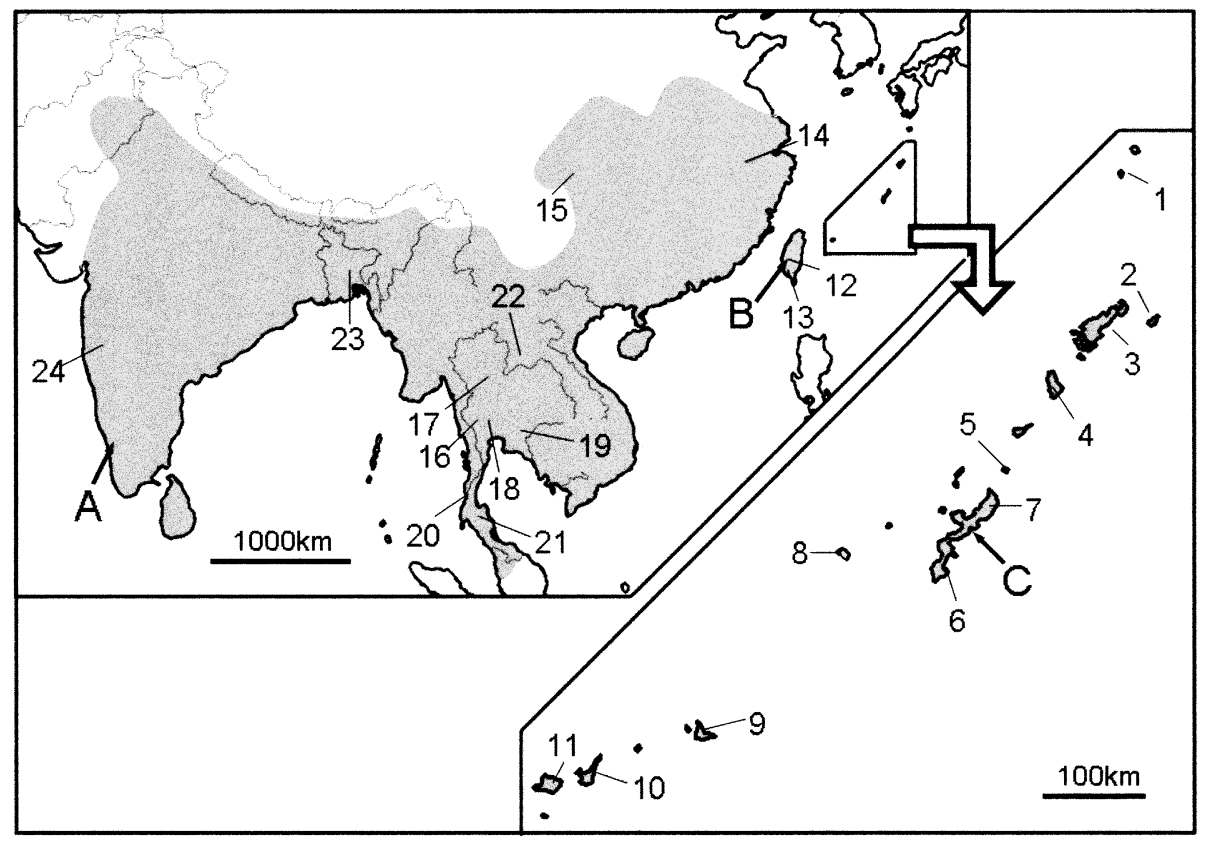

Fig. 1. A map of East to South Asia, showing known range (after Dutta, 1997; Maeda and Matsui, 1999; Fei, 1999; Schleich and Kastle, 2002) and sampling localities of Microhyla ornata (sensu lato). For the locality number, refer to Table 1. A, B, and C indicate type localities of M. ornata, M. fissipes, and $M$. okinavensis, respectively.

Since the description by Duméril and Bibron (1841), several authors proposed different names to different populations of $M$. ornata, but all these are now placed in the synonymy of this nominate species (Frost, 2004). Dubois (1987) recently revived one of such names originally described for a population from Okinawa of the Ryukyu Archipelago. Even if we simply admit his action to recognize distinct specific status of this and adjacent Ryukyu populations, the taxonomic status of populations occurring in the broad area between India and the Ryukyus remains equivocal. Moreover clarification of exact extent of any one species in both taxonomic and geographical senses is indispensable to discuss various issues relevant to biodiversity and biogeography.

Our preliminary analyses of partial sequences of mitochondrial cytochrome $b$ (mt cyt-b) gene revealed great genetic differentiations between populations of $M$. ornata from the Ryukyus, and Taiwan, continental China and Thailand (Matsui et al., unpublished). In this study, we compared $M$. ornata from India with conspecific populations from Southeast and East Asia using mt-DNA sequences. The results, while confirming the distinctness of the Ryukyu populations at the species level, clarified the presence of another distinct species within M. ornata (sensu lato) for the first time.

\section{MATERIALS AND METHODS}

\section{Sampling strategy}

In order to examine gross phylogenetic relationships among Microhyla, we first obtained partial sequences of 12S rRNA (ca. 860 $\mathrm{bp}$ ) and $16 \mathrm{~S}$ rRNA (ca. $860 \mathrm{bp}$ ) for five species of the genus, includ- ing M. ornata (sensu lato) from three disjunct regions (Fig. 1). Glyphoglossus molossus Günther, 1869 was also added to the subject, because our preliminary survey among the Oriental microhylids strongly suggested its close affinity with the Microhyla species (Matsui et al., unpublished). We selected Kaloula pulchra Gray, 1831 as an outgroup (Table 1). We then compared more detailed relationships among populations of $M$. ornata, with Glyphoglossus molossus as an outgroup using partial sequences of cytochrome b gene (cyt-b: <629 bp). This domain, known to exhibit more rapid nucleotide substitutions than rRNA genes, is considered to be more informative in examining relationships among conspecific populations or closely related, poorly diverged species (Koike and Matsui, 2003).

\section{Preparation of DNA, PCR, and DNA sequencing}

DNA was extracted from small amounts of frozen or ethanol preserved tissues using standard Phenol-Chloroform extraction procedures (Hillis et al., 1996). Amplification were done by the polymerase chain reaction (PCR), using the primers 12Sh (Cannatella et al., 1998) and H1548: 5'-TAC CAT GTT ACG ACT TTC CTC TTC T-3' made in the present study for $12 \mathrm{~S}$, the primers $16 \mathrm{~L} 2$ (Hedges et al., 1993) and 16SH1 (Hedges, 1994) for 16S, and the primers L14883: 5'-TCT GCT TAA TTG CTC AAA TCG C-3' and H15548: 5'-AAT AGG AAG TAC CAC TCT GGT TTA AT3' made in the present study, and H15502 (Tanaka-Ueno et al., 1998) for cytb. The numbering system followed the human sequence (Anderson et al., 1981). The amplified fragments were sequenced in an automated DNA sequencer (ABI PRISM 3100) using the PCR primers and following the manufacturers instructions. Newly obtained sequences were deposited in GenBank (Table 1).

\section{Phylogenetic analysis}

Sequences were aligned using the default parameters of ClustalX 1.83 (Thompson et al., 1997). For nucleotide sequences, the $12 \mathrm{~S}$ and $16 \mathrm{~S}$ were combined into a single data set of ca. $1720 \mathrm{bp}$. Maximum-parsimony (MP), neighbor-joining (NJ), and maximum likelihood (ML) phylogenies were calculated using PAUP*4.0b10 (Swofford, 2002). Pairwise comparisons of corrected sequence divergences [Kimura-2 parameter (K2p) distances (Kimura, 1980)] 
Table 1. Samples used in this study and GenBank accession numbers.

\begin{tabular}{|c|c|c|c|c|c|}
\hline \multirow{2}{*}{ Species } & \multirow{2}{*}{ Locality* } & \multirow{2}{*}{ Voucher** } & \multicolumn{3}{|c|}{ Accession number } \\
\hline & & & $12 S$, & $16 S$ & cyt-b \\
\hline Microhyla ornata & Ryukyu, Tokara, Suwanosejima (1) & KUHE11965 & - & - & , AB201195 \\
\hline Microhyla ornata & Ryukyu, Amami, Kikaijima (2) & KUHE33968 & - & - & , AB201196 \\
\hline Microhyla ornata & Ryukyu, Amami, Amamioshima (3a) & KUHE12840 & AB201173, & AB201184, & , AB201197 \\
\hline Microhyla ornata & Ryukyu, Amami, Amamioshima (3b) & KUHE32563 & - & - & , AB201198 \\
\hline Microhyla ornata & Ryukyu, Amami, Tokunoshima (4) & KUHE24172 & - & - & , AB201199 \\
\hline Microhyla ornata & Ryukyu, Amami, Yoronjima (5a) & KUHE34982 & - & - & , AB201200 \\
\hline Microhyla ornata & Ryukyu, Amami, Yoronjima (5b) & KUHE34984 & - & - & , AB201201 \\
\hline Microhyla ornata & Ryukyu, Okinawa, Okinawajima (6) & KUHE24489 & - & - & , AB201202 \\
\hline Microhyla ornata & Ryukyu, Okinawa, Okinawajima (7a) & KUHE22554 & - & - & , AB201203 \\
\hline Microhyla ornata & Ryukyu, Okinawa, Okinawajima (7b) & KUHE33444 & - & - & , AB201204 \\
\hline Microhyla ornata & Ryukyu, Okinawa, Kumejima (8) & KUHE12708 & - & - & , AB201205 \\
\hline Microhyla ornata & Ryukyu, Miyako, Miyakojima (9a) & KUHE32473 & - & - & , AB201206 \\
\hline Microhyla ornata & Ryukyu, Miyako, Miyakojima (9b) & KUHE33966 & - & - & , AB201207 \\
\hline Microhyla ornata & Ryukyu, Yaeyama, Ishigakijima (10) & KUHE29773 & - & - & , AB201208 \\
\hline Microhyla ornata & Ryukyu, Yaeyama, Iriomotejima (11a) & KUHE24920 & - & - & , AB201209 \\
\hline Microhyla ornata & Ryukyu, Yaeyama, Iriomotejima (11b) & KUHE22403 & - & - & , AB201210 \\
\hline Microhyla ornata & Taiwan, Jiayi (12) & KUHE12962 & - & - & , AB201211 \\
\hline Microhyla ornata & Taiwan, Gaoxiong (13) & KUHE32759 & - & - & , AB201212 \\
\hline Microhyla ornata & China, Anhui, Huangshan (14) & KUHE32943 & AB201174, & AB201185, & , AB201213 \\
\hline Microhyla ornata & China, Sichuan, Chengdu (15) & KUHE27705 & - & - & , AB201214 \\
\hline Microhyla ornata & Thailand, Kanchanaburi, Thong Pha Phum (16) & KUHE35165 & AB201175, & AB201186, & , AB201215 \\
\hline Microhyla ornata & Thailand, Phrae (17) & KUHE21982 & - & - & , AB201216 \\
\hline Microhyla ornata & Thailand, Bangkok (18) & KUHE22064 & - & - & , AB201217 \\
\hline Microhyla ornata & Thailand, Chanthaburi, Namtok Phliu (19) & KUHE34130 & - & - & , AB201218 \\
\hline Microhyla ornata & Thailand, Ranong (20) & KUHE23891 & - & - & , AB201219 \\
\hline Microhyla ornata & Thailand, Khaosok (21) & KUHE19687 & - & - & , AB201220 \\
\hline Microhyla ornata & Laos, Vientiane (22) & KUHE34324 & - & - & , AB201221 \\
\hline Microhyla ornata & Bangladesh, Dinajpur, Parbatipur (23) & DB-Hi-FROG12005 & AB201176, & AB201187, & , AB201222 \\
\hline Microhyla ornata & India, Karnataka, Dharwad (24) & ZSIK-A9119 & AB201177, & AB201188, & , AB201223 \\
\hline Microhyla butleri & Thailand, Bangkok & KUHE33557 & AB201178, & AB201189, & - \\
\hline Microhyla heymonsi & Thailand, Kanchanaburi, Thong Pha Phum & KUHEK1845 & AB201179, & AB201190, & - \\
\hline Microhyla pulchra & Thailand, Kanchanaburi, Thong Pha Phum & KUHE35119 & AB201180, & AB201191, & - \\
\hline Microhyla rubra & India, Karnataka, Dharwad & released & AB201181, & AB201192, & - \\
\hline Glyphoglossus Molossus & Thailand, Tak, Barrntak & KUHE35182 & AB201182, & AB201193, & - \\
\hline Glyphoglossus Molossus & Thailand, Tak, Barrntak & KUHE35182 & - & - & , AB201225 \\
\hline Kaloula pulchra & Thailand, Kanchanaburi, Thong Pha Phum & KUHE35171 & AB201183 & AB201194, & - \\
\hline
\end{tabular}

*Locality numbers correspond to those of Fig. 1; ${ }^{* *} \mathrm{KUHE}=$ Graduate School of Human and Environmental Studies, Kyoto University; DB-HiFROG=Laboratory for Amphibian Biology, Hiroshima University; ZSIK=Zoological Survey of India, Kolkata.

were also calculated with PAUP. The best-fitting model of sequence evolution for ML analysis was obtained by Modeltest 3.06 (Posada and Crandall, 1998). NJ trees were based on $\mathrm{TrN}+\mathrm{I}+\mathrm{G}$ distance (Tamura and Nei, 1993). Heuristic searches were performed using 10 replicates of a stepwise addition and tree bisection-reconnection (TBR) branch swapping. For MP, all characters were weighted equally, and gaps were treated as missing data. The bootstrap technique was used to test the reliabilities of the MP, NJ, and ML trees (2000, 2000, 100 replicates, respectively). Bayesian inference was conducted with MRBAYES 3.0 (Huelsenbeck and Ronquist, 2001) using GTR substitution model with 1,000,000 generations, sampling trees every 100th generation, and calculating a consensus tree after omitting the first 2000 trees. 


\section{RESULTS}

\section{Characteristics of combined genes}

The length of the combined 12S and 16S rRNA gene fragment varied from 1716 to $1727 \mathrm{bp}$ among the 11 specimens examined, and the aligned 12S and 16S rRNA data set consisted of 1752 nucleotide positions. Of these sites, 508 were variable, and 322 were informative for parsimony analyses. For cyt-b, we obtained 30 sequences with a total length of $629 \mathrm{bp}$, of which 221 sites were variable and 182 were parsimoniously informative.

Modeltest suggested a $\mathrm{TrN}+\mathrm{l}+\mathrm{G}$ substitution model with a gamma distribution shape parameter of 0.4202 as best fitting the combined $12 \mathrm{~S}$ and 16S rRNA data set. The best model for cyt-b was the $\mathrm{TrN}+\mathrm{I}+\mathrm{G}$ model with gamma distribution shape parameters of 1.2504 .

\section{Relationships among Microhyla}

All phylogenetic analyses based on 12S and 16S rRNA resulted in essentially the same topologies, and only the $\mathrm{ML}$ tree $(-\ln L=7333.36871)$ is shown in Fig. 2. Maximum parsimony searches recovered single most parsimonious tree of 1131 steps $(\mathrm{Cl}=0.639 ; \mathrm{Rl}=0.446)$. From four analyses with sufficient resolution, monophyly of Microhyla against Glyphoglossus molossus and the outgroup, Kaloula pulchra, was confirmed (support: 98, 99, 99, and 100\%: MP, NJ, ML bootstrap p-values, and Bayesian posterior probability, respectively). Within Microhyla, $M$. butleri was sister to the clade including all remaining species, although the support was very weak $(83,52,54$, and $-\%)$. The latter assemblage was further split into two subclades. In one of these subclades, $M$. rubra and $M$. ornata from India and Bangladesh proved to be a monophylum (support: $100 \%$ each), and $M$. rubra was sister to the latter two populations of $M$. ornata $(99,99,100$, and $100 \%)$. In subclade with less supports (57,

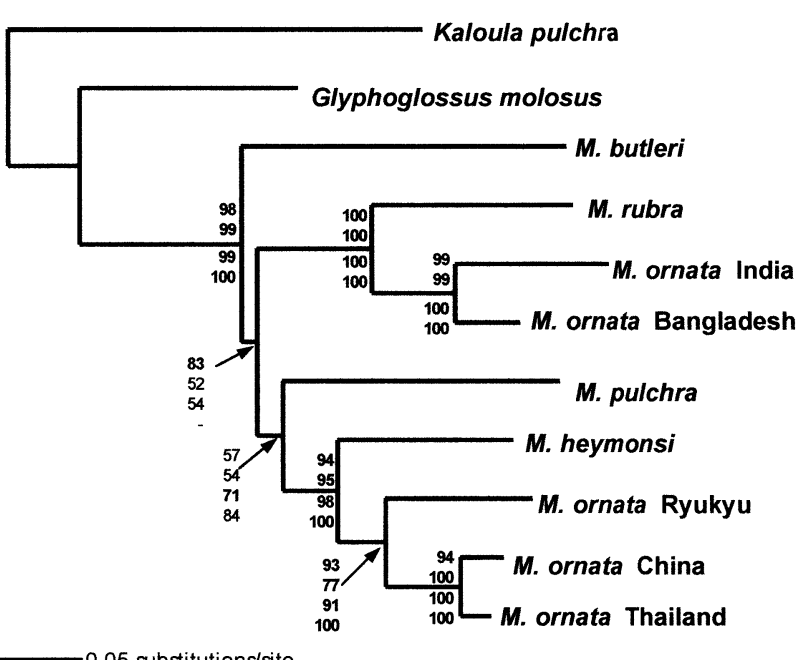

Fig. 2. Maximum likelihood tree of $1752 \mathrm{bp}$ of $12 \mathrm{~S}$ and $16 \mathrm{~S}$ rRNA for five species of Microhyla, Glyphoglossus molossus, and an outgroup Kaloula pulchra. Bootstrap supports are given in the order for MP (2000 replicates), NJ (2000), ML (100), and Bayesian inference.
$54,71$, and $84 \%), M$. pulchra was sister to the monophyletic group consisting of $M$. heymonsi and $M$. ornata from Southeast and East Asia (94, 95, 98, and 100\%). Populations of $M$. ornata from Southeast and East Asia were also monophyletic (93, 77, 91, and 100\%), and those from the Ryukyu Archipelago were collectively sister to populations from continental China and Thailand (94, 100, 100, and 100\%).

Within M. ornata, genetic divergence between the Chinese and Thai populations was small (sequence divergence $=3.0 \%$ and $2.5 \%$ in $12 \mathrm{~S}$ and $16 \mathrm{~S}$ rRNA, respectively). Populations from India and Bangladesh differed more greatly (6.1 and $7.0 \%)$, and even greater divergence was observed between populations from the Ryukyu Archipelago, and continental China and Thailand (6.8\% and $8.6 \%)$. These latter values were almost comparable to the minimal values observed between two other distinct species, M. pulchra and M. heymonsi (9.4\% and $13.3 \%)$.

\section{Relationships among Microhyla ornata}

All phylogenetic analyses based on cyt-b yielded similar topologies and only the ML tree $(-\mathrm{InL}=3277.68783)$ is shown in Fig. 3. Maximum parsimony searches recovered eight equally parsimonious trees of 557 steps $(\mathrm{Cl}=0.569$; $\mathrm{Rl}=0.840$ ). Both of the two assemblages, one consisting of populations from India and Bangladesh (support: 87, 52, -, and $99 \%$ ) and the other of the remaining East and Southeast Asian populations $(97,100,100$, and $100 \%$ ), proved to be monophyletic. The latter assemblage tended to be split into two clades, one including Thailand, Laos, China and Taiwan populations (100, 92, 96, and $100 \%)$, and the other encompassing Ryukyu populations (51, 75, 80 , and $89 \%$ ). The first clade was further divided into two subclades, one consisting of China and Taiwan (100, 95, 96, and 99\%), and the other of the Lao and Thai populations (80, 95, 94, and $99 \%)$. The second clade also included two subclades; one

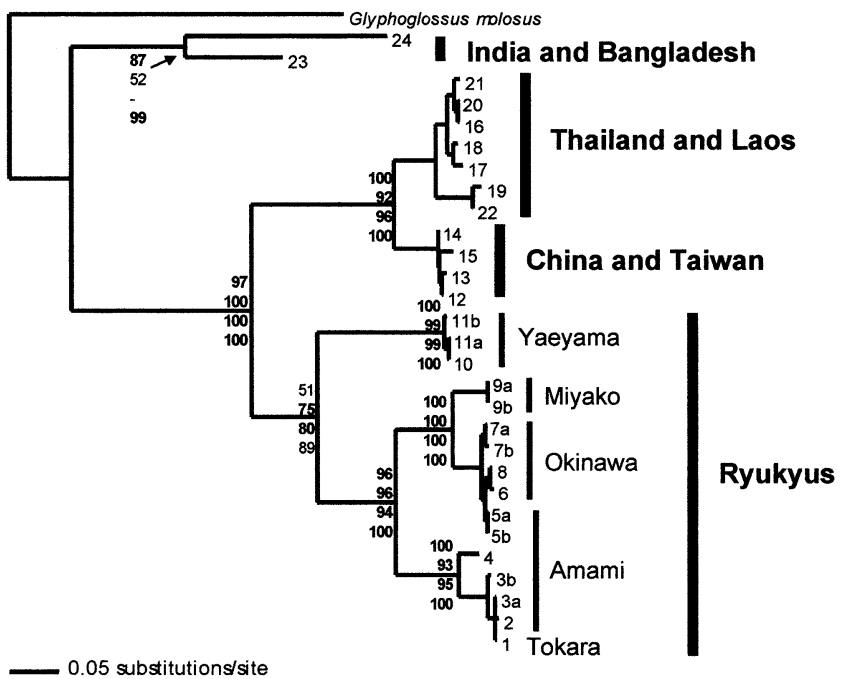

Fig. 3. Maximum likelihood tree of $629 \mathrm{bp}$ of cytochrome $\mathrm{b}$ for all populations of Microhyla ornata (sensu lato). Bootstrap supports are given in the order for MP (2000 replicates), NJ (2000), ML (100), and Bayesian inference. 
composed of the Yaeyama populations $(100,99,99$, and $100 \%$ ) and the other of the remaining Ryukyu populations $(96,96,94$, and $100 \%)$. In the latter subclade, northern populations from the Tokara and most of the Amami Groups $(100,93,95$, and $100 \%)$ and southern populations from part of the Amami, the Okinawa, and the Miyako Groups (100, 100,100 , and $100 \%$ ) were clearly separated.

Sequence divergences of the South Asian clade from the China-Thailand clade and the Ryukyu clade were great, being $19.1-24.0 \%$ and $18.4-21.1 \%$, respectively. The latter two clades also showed great sequence divergences (16.1$20.6 \%$, whereas the divergence within the South Asian clade was also large (15.4\%). In the China-Thailand clade, the two subclades showed the divergence of $8.2-11.0 \%$, which is smaller than that observed between the two subclades of the Ryukyu clade (13.3-16.7\%). In the second subclade of the Ryukyu clade, the northern and the southern populations were also fairly divergent (11.3-13.8\%).

\section{DISCUSSION}

The results of analyses of the mitochondrial $12 S$ and $16 S$ rRNA data strongly suggest that $M$. ornata (sensu lato) is a composite of at least two discrete lineages, because the clade consisting of populations from South Asia was shown to be sister to M. rubra rather than to the other "conspecific" clade encompassing populations from Southeast and East Asia. Likewise, the latter clade constituted a monophyletic group together with $M$. pulchra and M. heymonsi in the phylogenetic trees.

The locality where the type specimen of $M$. ornata

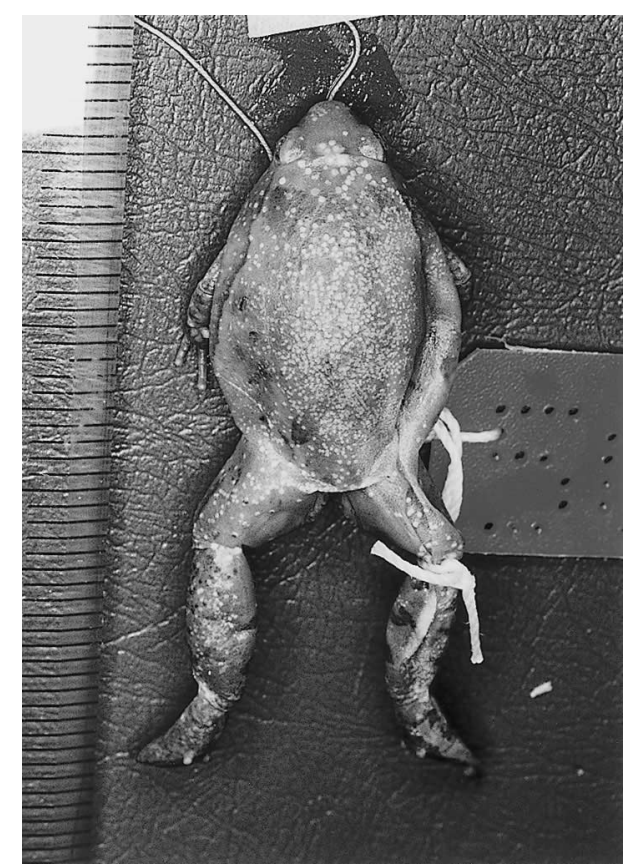

Fig. 4. The holotype of Microhyla ornata from India (Muséum National d'Histoire Naturelle, Paris 5035, Snout-vent length $=22.7$ $\mathrm{mm})$.
(MNHNP 5035: Fig. 4) was obtained is reported to be "côte Malabar", India (Duméril and Bibron, 1841), and our Indian sample was obtained from a locality not much far from the type locality. The population from Bangladesh was sister to the Indian population, but, as shown by great divergence value, fairly differed genetically from the latter. This may suggest the presence of more than one species within the South Asian populations of $M$. ornata.

Populations from Southeast and East Asia formed a monophylum, which is not sister to the one including $M$. ornata (sensu stricto), in our phylogenetic trees (see above), and it is thus obvious that those populations do not belong to M. ornata. Furthermore, of the Southeast and East Asian populations, the Ryukyu populations are suspected to be split from the remainder at the species rank, since the level of genetic divergence between them largely overlapped those between each of them and of $M$. ornata (sensu stricto), and was close to the values obtained for combinations of other distinct species such as $M$. pulchra and $M$. heymonsi. Lai et al. (1996) studied phylogenetic relationships among populations of four microhylid species from Taiwan and the Ryukyu Islands (Iriomotejima and Kumejima) through analyses of allozyme variations. In their results, Taiwan populations of $M$. ornata formed a distinct group and split from a group including three other species and Ryukyu populations of $M$. ornata. In the latter group, $M$. ornata from Kumejima was sister to the clade encompassing populations of $M$. heymonsi and $M$. ornata from Iriomotejima. These curious relationships are completely different from those obtained by us (see results) and might have resulted from misinterpretations of allozyme data. The different inheritance mechanisms of mitochondrial and nuclear markers (e.g., Avise, 2000; Kim et al., 2004) cannot be ruled out, but, even so, their results do not contradict, but strengthen, our taxonomic idea to split populations from Taiwan and the Ryukyu Islands.

Our analyses, although showing certain degrees of genetic divergences among populations from Taiwan, China, Thailand, and Laos, yielded no convincing support to the further specific split of the Southeast and East Asian assemblages exclusive of the Ryukyu populations. Very few studies have been made to estimate variation within this assemblage. Acoustic characteristics are reported to be similar between Taiwan and Thailand populations (Kuramoto, 1987). Our preliminary analyses of calls recorded in Anhui, China, and many localities in Thailand also failed to detect any notable difference (Matsui, unpublished data). Flower (1899) stated that there are some morphological differences in both adults and tadpoles of $M$. ornata between the Malay Peninsula and Indochina. Liu (1950) described the cloacal tail piece in tadpoles of $M$. ornata from western continental China as dextral, although this organ is medial in tadpoles from Taiwan (Chou and Lin, 1997), as well as in those from the Ryukyu Archipelago (Shimizu and Ota, 2003). Validity and taxonomic significance of such variations in the continental-Taiwanese assemblage require future ver- 
ification and considerations.

The oldest available name applicable to the frogs in this region is $M$. fissipes Boulenger, 1884 [type loclity=Taiwanfoo (=Tainan), S. Formosa (Taiwan)]. Microhyla fissipes is reported to be morphologically very similar to $M$. ornata (sensu stricto) by Parker (1934), who synonymized it with the latter. Khan (2000), however, argued that tadpoles of $M$. ornata from northeastern Pakistan, South Asia, are differentiated from those from Thailand by several characteristics, such as longer infralabial papillae, more filter rows, and the presence of postnarial membraneous ridge. Future study is needed to examine the validity of these differences in discriminating $M$. ornata (sensu stricto) from $M$. fissipes as a whole. It is also strongly desired to find out reliable diagnostic characteristics for adults of these species.

The populations from the Ryukyu Archipelago were originally described as a distinct species M. okinavensis by Stejneger (1901) [type loclity=Okinawa Shima, Riu Kiu (=Ryukyu) Archipelago, Japan], but later relegated to the synonymy of M. ornata (Inger, 1947). In establishing subgenera in Microhyla, Dubois (1987) simply resurrected this old name, but without any comment for this change. Duellman (1993) "automatically" adopted this treatment, and Zhao (1999) listed both M. ornata and M. okinavensis in the fauna of the Ryukyus. From our results, it is now obvious that the population from the Ryukyu Archipelago should be separated not only from $M$. ornata from India, but also from $M$. fissipes, as a distinct species $M$. okinavensis. From $M$. ornata (sensu stricto) and $M$. fissipes, $M$. okinavensis can be distinguished by the combination of morphological characteristics (shape of the loreal region, relationships of interorbital and upper eyelid widths, shape of toe tips, presence or absence of a median cleft on surfaces of digits, presence or absence of lateral fringes on toes, and position of tibio-tarsal articulation when hindlimb is bent forwards along body: Parker, 1934). In the embryonic development, M. okinavensis may differ from $M$. fissipes in the timing of a few important changes, such as darkening of the stomodium area (the neural fold stage vs. neural tube stage: Shimizu and Ota, 2003). The egg diameter is reportedly larger in M. okinavensis than in $M$. fissipes (mean=0.97-1.20 mm vs. 0.90: Matsui and Ota, 1984; Liu et al., 1996; Shimizu and Ota, 2003). Acoustically, M. okinavensis and $M$. fissipes are slightly different as already reported by Kuramoto (1987).

From our results, lesser, but yet substantial degrees of genetic differentiations are demonstrated for a few combinations of populations of $M$. okinavensis, such as those from Yaeyama and from the other islands of the Ryukyus, and from southern and northern islands of the Miyako to Tokara Groups. The egg diameter of the Okinawajima population (0.93-1.04 mm, mean=0.97, SD=0.04) is substantially smaller than that of the Yaeyama populations (1.00-1.30 $\mathrm{mm}$, mean=1.20, SD=0.03). Furthermore, Kuramoto (1976) has suggested presence of differences in acoustic characteristics between populations of $M$. okinavensis (as $M$. ornata), but detailed studies are still lacking. It is necessary to morphologically and acoustically reassess relationships among populations of $M$. okinavensis from its whole range of distribution in the Ryukyu Archipelago.

\section{ACKNOWLEDGMENTS}

Permissions for field works granted by the National Research Council of Thailand and the Royal Forest Department of Thailand are acknowledged with gratitude. K. Araya, T. Chan-Ard, T. Hikida, J. Nabhitabhata, and S. Panha are also acknowledged for their help in field trips. We thank S.-L. Cheng, U. Grafe, S. Ikeda, T. Kubota, N. Kuraishi, MT. Matsui, A. Mori, T. Sugahara, M. Sumida, S. Takenaka, I. Takiguchi, M. Toda, and M. Toyama who helped us greatly by providing material frogs. We are also much indebted to R. H. Bain and J.-T. Lin for provision of pertinent literature. A. Dubois and $\mathrm{A}$. Ohler kindly allowed $\mathrm{M}$. Matsui to examine the type specimen of $M$. ornata. This research was partially supported by Grants-in-Aid from the Ministry of Education, Science, Sports and Culture of Japan (Nos. 06041066, 07454234, 08041144, 10041166, 15370038) and National Geographic Society (No. 4505-91) to M. Matsui. Preparation of the ms was partially supported by a grant of the 21st Century COE to the University of the Ryukyus.

\section{REFERENCES}

Anderson S, Bankier AT, Barrell BG, de Bruijin MHL, Coulson AR, Drouin J, Eperon IC, Nierlich DP, Roe BA, Sanger F, Schreier $\mathrm{PH}$, Smith AJH, Staden R, Young, IG (1981) Sequence and organization of the human mitochondrial genome. Nature 290: $457-465$

Avise JC (2000) Phylogeography. Harvard University Press, Cambridge

Boulenger GA (1884) Descriptions of new species of reptiles and batrachians in the British Museum.-Part II. Ann Mag Nat Hist Ser 5 13: 396-398

Cannatella DC, Hillis DM, Chippindale PT, Weigt L, Rand AS, Ryan MJ (1998) Phylogeny of frogs of the Physalaemus pustulosus species group, with an examination of data incongruence. Syst Biol 47: 311-335

Chou W-H, Lin J-Y (1997) Tadpoles of Taiwan. Spec Publ Natn Mus Nat Sci Taichung 7: 1-98

Dubois A (1987) Miscellanea taxinomica batrachologica (II). Alytes 6: $1-9$

Duellman WE (1993) Amphibian species of the world: additions and corrections. Univ Kansas Mus Nat Hist Spec Publ 21: 1-372

Duméril AMC, Bibron G (1841) Erpétologie générale ou histoire naturelle complete des Reptiles Tome 8. Roret, Paris

Dutta SK (1997) Amphibians of India and Sri Lanka (Checklist and Bibliography). Odyssey Publishing House, Bhubaneswar

Fei L (Ed) (1999) Atlas of Amphibians of China. Henan Science and Technology Press, Zhengzhow

Flower SS (1899) Notes on a second collection of batrachians made in the Malay peninsula and Siam from November 1896 to September 1898, with a list of the species recorded from these countries. Proc Zool Soc Lond 1899: 885-916

Frost DR (Ed) (1985) Amphibian Species of the World: A Taxonomic and Geographical Reference. Allen Press, Lawrence

Frost DR (2004) Amphibian Species of the World: an Online Reference. Version 3.0 (22 August, 2004). Electronic Database accessible at http: //research.amnh.org/herpetology/amphibia/ index.html. American Museum of Natural History, New York

Hedges SB (1994) Molecular evidence for the origin of birds. Proc Natl Acad Sci USA 91: 2621-2624

Hedges SB, Nussbaum RA, Maxson LR (1993) Caecilian phylogeny and biogeography inferred from mitochondrial DNA sequences 
of the 12S rRNA and 16S rRNA genes (Amphibia: Gymnophiona). Herpetol Monogr 7: 64-76

Huelsenbeck JP, Ronquist FR (2001) MrBayes: Bayesian inference of phylogenetic trees. Bioinformatics 17: 754-755

Hillis DM, Mable BK, Larson A, Davis SK, Zimmer EA (1996) Nucleic acids IV: Sequencing and cloning. In "Molecular Systematics" Ed by DM Hillis, C Moritz, BK Mable, Sinauer Associates, Sunderland, MA, pp 321-378

Hirai T, Matsui M (2000) Ant specialization in diet of narrowmouthed toad, Microhyla ornata, from Amamioshima island of the Ryukyu Archipelago. Cur Herpetol 19: 27-34

Inger RF (1947) Preliminary survey of the amphibians of the Riukiu Islands. Fieldiana: Zool 32: 295-352

Inger RF (1999) Distribution of amphibians in Southern Asia and adjacent islands. In "Patterns of Distribution of Amphibians: A Global Perspective" Ed by WE Duellman, Johns Hopkins Univ Press, Baltimore, pp 445-482

Khan MS (2000) Buccopharyngeal morphology and feeding ecology of Microhyla ornata tadpoles. Asiatic Herpetol Res 9: 130-138

Kim J-B, Matsui M, Lee J-E, Min M-S, Suh J-H, Yang S-Y (2004) Notes on a discrepancy in mitochondrial DNA and allozyme differentiation in pond frog Rana nigromaculata. Zool Sci 21: 3942

Kimura M (1980) A simple method for estimating evolutionary rates of base substitutions through comparative studies of nucleotide sequences. J Mol Evol 16: 111-120

Koike H, Matsui M (2003) Conservation Genetics. Univ Tokyo Press, Tokyo

Kuramoto M (1976) Mating calls of the frog, Microhyla ornata, from the Ryukyu islands. Bull Fukuoka Univ Educ III 26: 91-93

Kuramoto M (1987) Advertisement calls of two Taiwan microhylid frogs, Microhyla heymonsi and M. ornata. Zool Sci 4: 563-567

Lai BC G, Lue KY, Tong WF (1996) Preliminary study of biogeography and phylogeny of Microhylidae between Taiwan and Ryukyu Islands. Biol Bull Nat Taiw Norm Univ (Spec Iss) 31: 83-92

Liu CC (1950) Amphibians of western China. Fieldiana: Zool Mem 2: $1-400$

Liu S, Song Z, Zhong J, He M (1996) Study on early embryonic development in Microhyla ornata. J Sichuan Univ (Nat Sci Ed) 33: 323-329

Maeda N, Matsui M (1999) Frogs and Toads of Japan, Revised Edition. Bun-ichi Sogo Shuppan, Tokyo

Matsui M (1994) A taxonomic study of the Rana narina complex, with description of three new species (Amphibia: Ranidae). Zool J Linn Soc 111: 385-415

Matsui M, Chan-Ard T, Nabhitabhata J (1996) Distinct specific status of Kalophrynus pleurostigma interlineatus (Anura, Microhylidae). Copeia 1996: 440-445
Matsui M, Ota H (1984) Parameters of fecundity in Microhyla ornata from the Yaeyama Group of the Ryukyu Archipelago. Jpn J Herpetol 10: 73-79

Matsui M, Seto T, Utsunomiya T (1986) Acoustic and karyotypic evidence for specific separation of Polypedates megacephalus from $P$. leucomystax. J Herpetol 20: 483-489

Parker HW (1934) A Monograph of the Frogs of the Family Microhylidae. British Museum, London

Posada D, Crandall KA (1998) MODELTEST: testing the model of DNA substitution. Bioinformatics 14: 817-818

Schleich, HH, Kästle W (2002) Amphibians and Reptiles of Nepal. ARG. Ganther Verlag KG, Ruggell

Shimizu S, Ota H (2003) Normal development of Microhyla ornata: the first description of the complete embryonic and larval stages for the microhylid frogs (Amphibia: Anura). Cur Herpetol 22: 73-90

Stejneger $L$ (1901) Diagnoses of eight new batrachians and reptiles from the Riu Kiu Archipelago, Japan. Proc Biol Soc Washington 14: 189-191

Swofford DL (2002) PAUP*. Phylogenetic Analysis Using Parsimony ( ${ }^{*}$ and other methods). Version 4. Sinauer Associates, Sunderland, MA

Tamura K, Nei M (1993) Estimation of the number of nucleotide substitutions in the control region of mitochondrial DNA in humans and chimpanzees. Mol Biol Evol 10: 512-526

Tanaka-Ueno T, Matsui M, Chen S-L, Takenaka O, Ota H (1998) Phylogenetic relationships of brown frogs from Taiwan and Japan assessed by mitochondrial cytochrome b gene sequences (Rana: Ranidae). Zool Sci 15: 283-288

Thompson JD, Gibson TJ, Plewniak F, Jeanmougin F, Higgins, DG (1997) The Clustal $X$ windows interface: flexible strategies for multiple sequence alignment aided by quality analysis tools. Nucleic Acids Res 25: 4876-4882

Toda M, Matsui M, Nishida M, Ota H (1998) Genetic divergence among Southeast and East Asian populations of Rana limnocharis (Amphibia: Anura), with special reference to sympatric cryptic species in Java. Zool Sci 15: 607-613

Veith M, Kosuch J, Ohler A, Dubois A (2001) Systematics of Fejervarya limnocharis (Gravenhorst, 1829)(Amphibia, Anura, Ranidae) and related species. 2. Morphological and molecular variation in frogs from the Greater Sunda islands (Sumatra, Java, Borneo) with the definition of two species. Alytes 19: 528

Zhao E-M, (1999) Distribution patterns of amphibians in temperate eastern Asia. In "Patterns of Distribution of Amphibians: A Global Perspective" Ed by WE Duellman, Johns Hopkins Univ Press, Baltimore, pp 421-443

(Received January 11, 2004 / Accepted March 1, 2005) 


\section{ERRATA}

Volume 22, No. 4 (2005), in the article "Taxonomic Relationships within the Pan-Oriental Narrow-mouth Toad Microhyla ornata as Revealed by mtDNA Analysis (Amphibia, Anura, Microhylidae)" by Masafumi Matsui, Hiroharu Ito, Tomohiko Shimada, Hidetoshi Ota, Srinivas K. Saidapur, Wichase Khonsue, Tomoko Tanaka-Ueno and Guan-Fu Wu, page 489-495. for the reader's convenience, the corrections appear as follows;

page 495, Received date

11 January, 2004

(correct) 11 January, 2005 